\title{
Janina Katz
}

\section{Landskabet der blev væk}

Min families skatkiste

oppe på loftet. I luften.

Usynlig.

Øjnene der kunne se den

kan ikke længere se.

Er selv usynlige.

Hvad er det

jeg nu åbner

med mine levende hænder?

Hvad er det

jeg tager frem

støver af og pudser?

Dette kostbare ingenting

fyldt med sølvbægre

frugtskåle af blomstret porcelæn

bøger skrevet med sod.

Min længsel er stor og hævngerrig.

Blodtørstig som et udsultet dyr.

Den har kun ord

at spise sig mæt på.

Store ord

og små. 